\title{
A daily study of the diatom spring bloom at Roscoff (France) in 1985. II. Phytoplankton pigment composition studied by HPLC analysis
}

\author{
Bert Klein \& Alain Sournia \\ Station Biologique, F-29211 Roscoff, France
}

\begin{abstract}
Phytoplankton pigment composition was studied by means of HPLC during an 8 mo period with emphasis on the diatom spring bloom. Twenty-five different pigments were detected and their concentration pattems are shown. The pigment composition revealed that, besides diatoms, nannoplanktonic cryptomonads and green algae play an important role in the phytoplankton community of the coastal waters of Roscoff. High concentrations of chlorophyll a degradation products were never observed. Seven diffesent phaeophorbide a-like, 2 phaeophytin a-like and phaeophytin $b$ were detected. Correspondence analysis of pigment data can be used to show the dynamics of the phytoplankton community.
\end{abstract}

\section{INTRODUCTION}

The diatom spring bloom in the coastal waters of Roscoff (Northern Brittany, France) shows a species succession which often culminates in a nearly unialgal bloom of Rhizosolenia delicatula (Grall \& Jacques 1964, Grall 1972a, b). The nannoplankton is rather stable throughout the year (Grall 1972a). It consists mainly of cryptomonads and the other algal classes are quantitatively not important in these coastal waters (Grall 1972a, Riaux 1983).

The phytoplankton pigments in this region were studied until now by means of fluorometric or spectrophotometric methods (cf. Strickland \& Parsons 1968). These techniques do not differentiate between chlorophyll $a$, iso- and allomere chlorophyll $a$ and chlorophyllide $a$, or between phaeophytin $a$ and phaeophorbide $a$. This can lead to considerable errors in calculated pigment concentrations (cf. Lorenzen \& Jeffrey 1980, Gieskes \& Kraay 1983b, Conover et al. 1986). With chromatographic techniques (TLC and HPLC), nearly all pigments and their degradation products are separated and quantified accurately (e.g. Abaychi \& Riley 1979, Jeffrey 1981). The pigment composition can be used for chemotaxonomic purposes (e.g. Gieskes \& Kraay 1983a, 1986), as several pigments or pigment combinations are only found in cer- tain algal classes (cf. van den Hoek 1978, Parsons et al. 1984). Phaeophytin $a$, phaeophorbide $a$ and chlorophyllide $a$ have been reported as the major chlorophyll a degradation products (Lorenzen 1967, Jeffrey 1974, Gieskes \& Kraay 1980, Hallegraeff 1981, Gowen et al. 1983, Ridout \& Morris 1985, Bidigare et al. 1986, Trees et al. 1986). Chlorophyllide $a$ is a normal compound in the algal cell since it is an intermediate in the chlorophyll a synthesis (Meeks 1974). It can be found in high concentrations in senescent cells (Jeffrey 1974) and after superfluous feeding by copepods (Gieskes \& Kraay 1980). Phaeophytin a and phaeophorbide $a$ are the result of zooplankton grazing (cf. Daley 1973, Jeffrey 1974,1980 ). Recently some new chlorophyll a degradation products were detected: phaeophytin $a$ like and phaeophorbide a-like derivatives (Vernet 1983, Hallegraeff \& Jeffrey 1984, Engelkes 1985, Gieskes \& Kraay 1986, Hawkins et al. 1986, Marker et al. 1986, Roy 1986). However, in grazing experiments with the protozoan Oxyrrhis marina very little chlorophyll a was degraded to phaeophytin $a$ and none to phaeophorbide a (Klein et al. 1986) and Protozoa seem to be able to digest both chlorophylls and carotenoids to colourless residues (Burkill et al. 1986, Klein et al. 1986)

The present paper is the second of a series dealing with data from samples collected in the coastal waters 
of Roscoff (Sournia et al. 1987). It deals with the results of first detailed analyses of phytoplankton pigments during an 8 mo period in this region, reflecting clearly the dramatic phenomenon of the annual diatom spring bloom.

\section{MATERIALS AND METHODS}

The sampling station and sampling are described in detail by Sournia et al. (1987). Phytoplankton was enumerated using Utermöhl's sedimentation technique. Samples for pigment analysis were taken every fortnight from 14 January until 28 May and from 9 July until 23 August and daily from 1 June until 2 July (Julian Days 14 to 148, 190 to 235 and 152 to 183 respectively). The sample (generally 2 l) was filtered through Whatman GF/F filters. The filters were stored immediately at $-20^{\circ} \mathrm{C}$ until analysis in August. Filters were ground in 5 or $10 \mathrm{ml} 90 \%$ acetone in a Potter tissue grinder with a teflon pestle placed in a $0^{\circ} \mathrm{C}$ waterbath. The extract was centrifuged and filtered through a $0.5 \mu \mathrm{m}$ filter unit (Millex-SR, Millipore Corporation). Immediately before analysis $500 \mu \mathrm{l}$ of the pigment extract was mixed with $150 \mu \mathrm{l}$ PIC (ion-pairing agent: $1.5 \mathrm{~g}$ tetrabutylammonium acetate [Fluka] and $7.7 \mathrm{~g}$ ammonium acetate [Merck] in $100 \mathrm{ml}$ water, pH 7.1 [Mantoura \& Llewellyn 1983]). The water-soluble phycobiliproteins (major pigments of cryptomonads and cyanobacteria; cf. van den Hoek 1978, Parsons et al. 1984) were not determined in the present study. The sample was prepared in about $15 \mathrm{~min}$. This was done under dim light conditions.

The High Performance Liquid Chromatography (HPLC) system consisted of a Valco C6U injector (sample loop 100 or $250 \mu \mathrm{l}$ ) and 2 LDC-Milton Roy Constametric III pumps controlled by an Apple II+ compatible computer with 'The Gradient Programme' version 1.1 by D. Juda (1984; Medical Research Council, Toxicology Unit, Carshalton, U.K.). The pigments were separated on a column (25 cm, $4 \mathrm{~mm}$ i.d.) packed with Lichrosorb $7 \mu \mathrm{m} \mathrm{RP}-18$ (Merck). Solvent A consisted of $70 \%$ methanol (analytical or HPLC grade, Prolabo), $20 \%$ double-distilled deionized water and $10 \%$ PIC. Solvent B consisted of $80 \%$ methanol and $20 \%$ ethylacetate (Merck). The solvent program showed a linear increase of Solvent B from 20 to $60 \%$ in 7 min, a hold at $60 \%$ for $5 \mathrm{~min}$, a linear increase from 60 to $100 \%$ Solvent B from 12 to $20 \mathrm{~min}$, followed by a hold at $100 \%$ for $10 \mathrm{~min}$. The detection was carried out with a LDC-Milton Roy Spectromonitor III set at $440 \mathrm{~nm}$ and a LDC-Milton Roy Fluoromonitor III (excitation: $440 \mathrm{~nm}$; emission: 500 to $700 \mathrm{~nm}$ ). The chromatograms (Fig. 1) were recorded with a 2-channel recorder (Sefram or Linseis model L 6512). The injected quantity of the
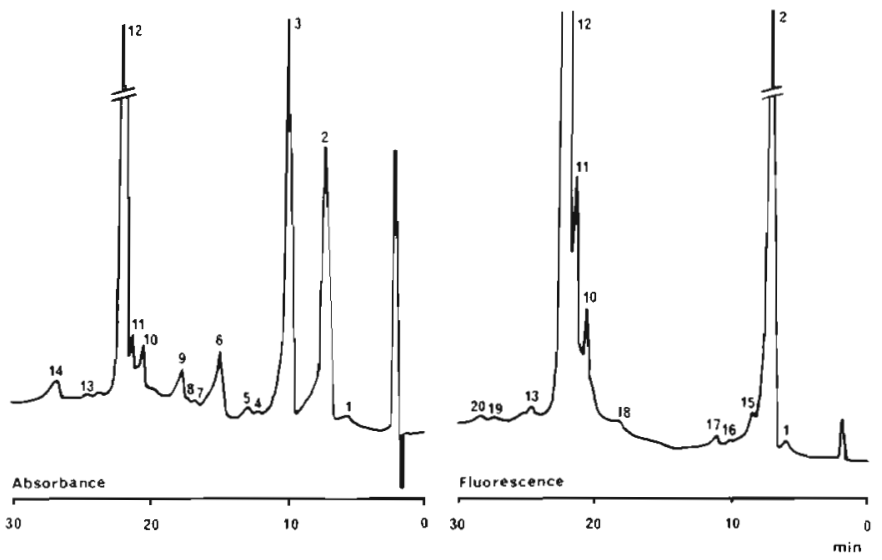

Fig. 1. Chromatogram (absorbance and fluorescence) of the pigment extract from the sample on Day 163. Pigments: 1 , chlorophyllide $a_{i} 2$, chlorophyll $c ; 3$, fucoxanthin; 4 , violaxanthin; 5, neofucoxanthin; 6 , diadinoxanthin; 7 , alloxanthin; 8 , diatoxanthin; 9, lutein; 10, chlorophyll $b ; 11$, allomere chlorophyll $a ; 12$, chlorophyll $a ; 13$, phaeophytin $b ; 14, \beta$ carotene; 15 , phaeophorbide a-like $2 ; 16$, phaeophorbide $a-$ like $4 ; 17$, phaeophorbide a-like $6 ; 18$, unknown chlorophyll a derivative; 19 , phaeophytin a; 20, phaeophytin a-like

pigments was determined by measuring peak heights. The identification of the pigments and the calibration of the apparatus was done as describeds by Gieskes \& Kraay (1984). The reproducibility of the peak heights (coefficient of variation) was less than $7 \%$.

Table 1. Pigments detected during the period Jan to Aug 1985. The composition of the major algal classes in coastal waters of Roscoff is indicated (cf. van den Hoek 1978, Parsons et al. 1984)

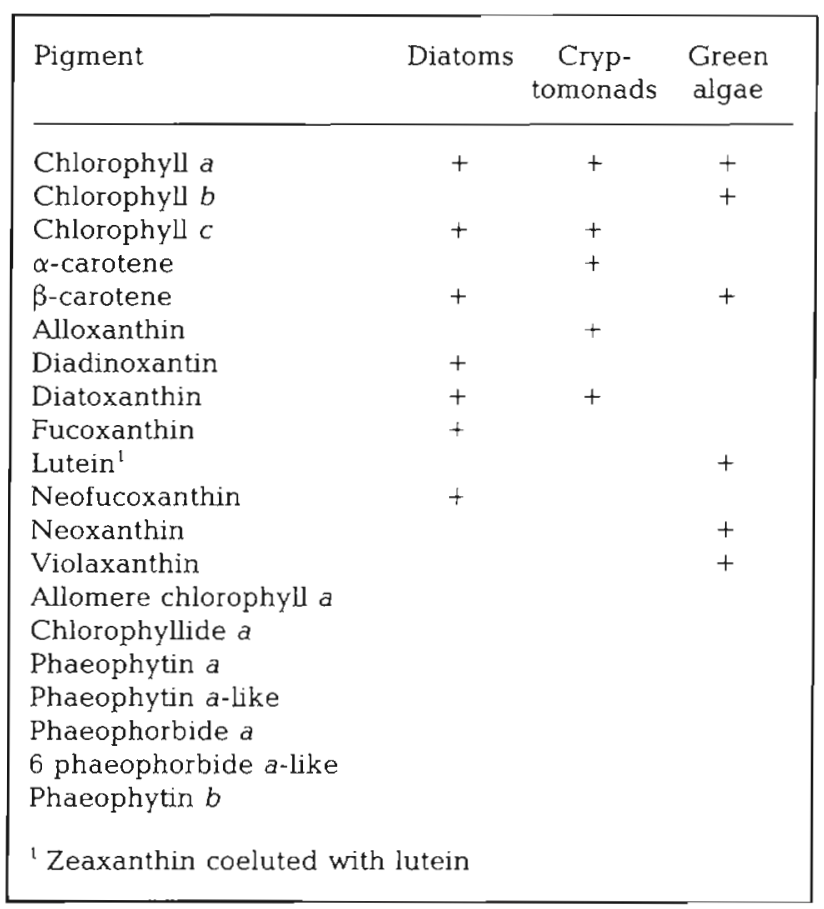




\section{RESULTS}

Throughout the 8 mo sampling period, 25 different pigments (Table 1), including 12 chlorophyll derivatives, were detected and quantified. Their concen- tration patterns are presented here in the same chemotaxonomic groupings as observed in the different algal classes (Table 1; cf. van den Hoek 1978, Parsons et al. 1984) followed by the different chlorophyll $a$ and chlorophyll $b$ derivatives.

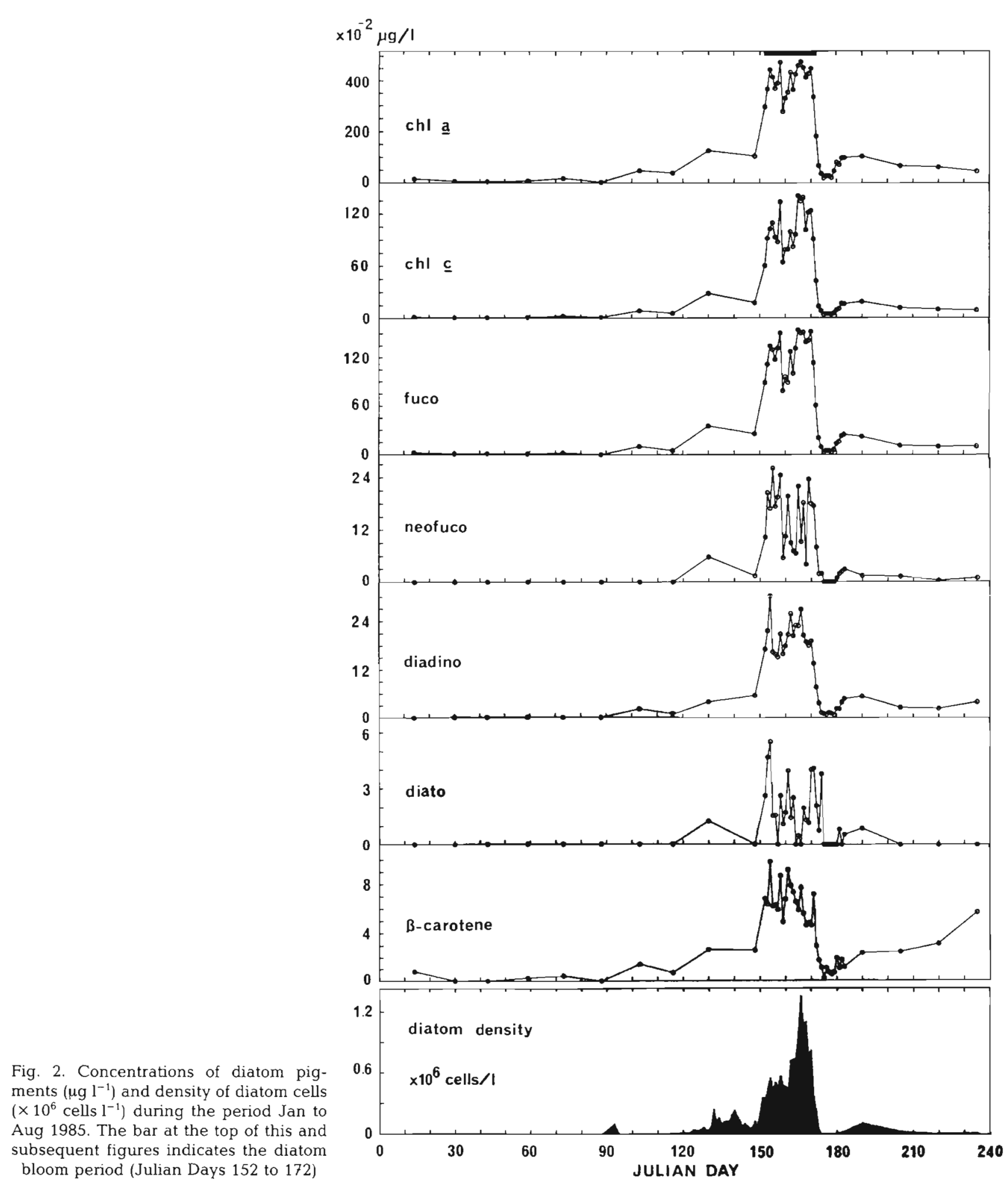




\section{Diatom pigments}

Most of the diatom pigment concentrations show a rather similar pattern (Fig. 2), except neofucoxanthin and diatoxanthin, which show much scattering. The pigment concentrations show clearly that the diatom bloom started between Julian Days 148 and 152 and declined from Day 170 on. There appear to be 2 periods separated by a period of lower concentrations (Days 159 to 161). The highest concentrations were observed during Days 158, 165, 166 and 167. The microphytoplankton was dominated by diatoms and the obtained results correspond fairly well with diatom cell densities (Fig. 2; for details see Sournia et al. 1987). However, the prominent cell density maximum at Day 166 is less evident in the pigment concentrations.

\section{Green algal pigments}

Chlorophyll $b$ and to a lesser extent lutein were detected throughout the studied period, indicating the presence of green algae. The concentrations of chlorophyll $b$, lutein, violaxanthin and neoxanthin are shown in Fig. 3 and of chlorophyll $a$ and $\beta$-carotene in
Fig. 2. Zeaxanthin co-eluted with lutein. Chlorophyll $b$ and lutein show similar concentration patterns. Violaxanthin shows much scattering and neoxanthin was only detected at the end of the studied period. Chlorophyll $b$ and lutein obtained their maximum concentration at Day 161. On this day, diatom cell numbers began to increase and the diatom pigment concentrations were somewhat lower (cf. Fig. 2). Surprisingly, chlorophyll $b$ and lutein concentrations decreased at the same time as diatom pigment concentrations (Days 171 to 174). Since nannoplankton cell counts are not available, it is not possible to say whether variations in pigment concentrations were caused by variations in green algal densities or by variations in pigment content per cell.

\section{Cryptomonad pigments}

The xanthophyll alloxanthin was detected in most samples, indicating the presence of cryptomonads. The concentrations of the acetone-soluble pigments alloxanthin and $\alpha$-carotene are shown in Fig. 4 and chlorophyll $a$, chlorophyll $c$ and diatoxanthin in Fig. 2. The typical cryptomonad pigments (alloxanthin and $\alpha$ carotene) show a rather different concentration pattern

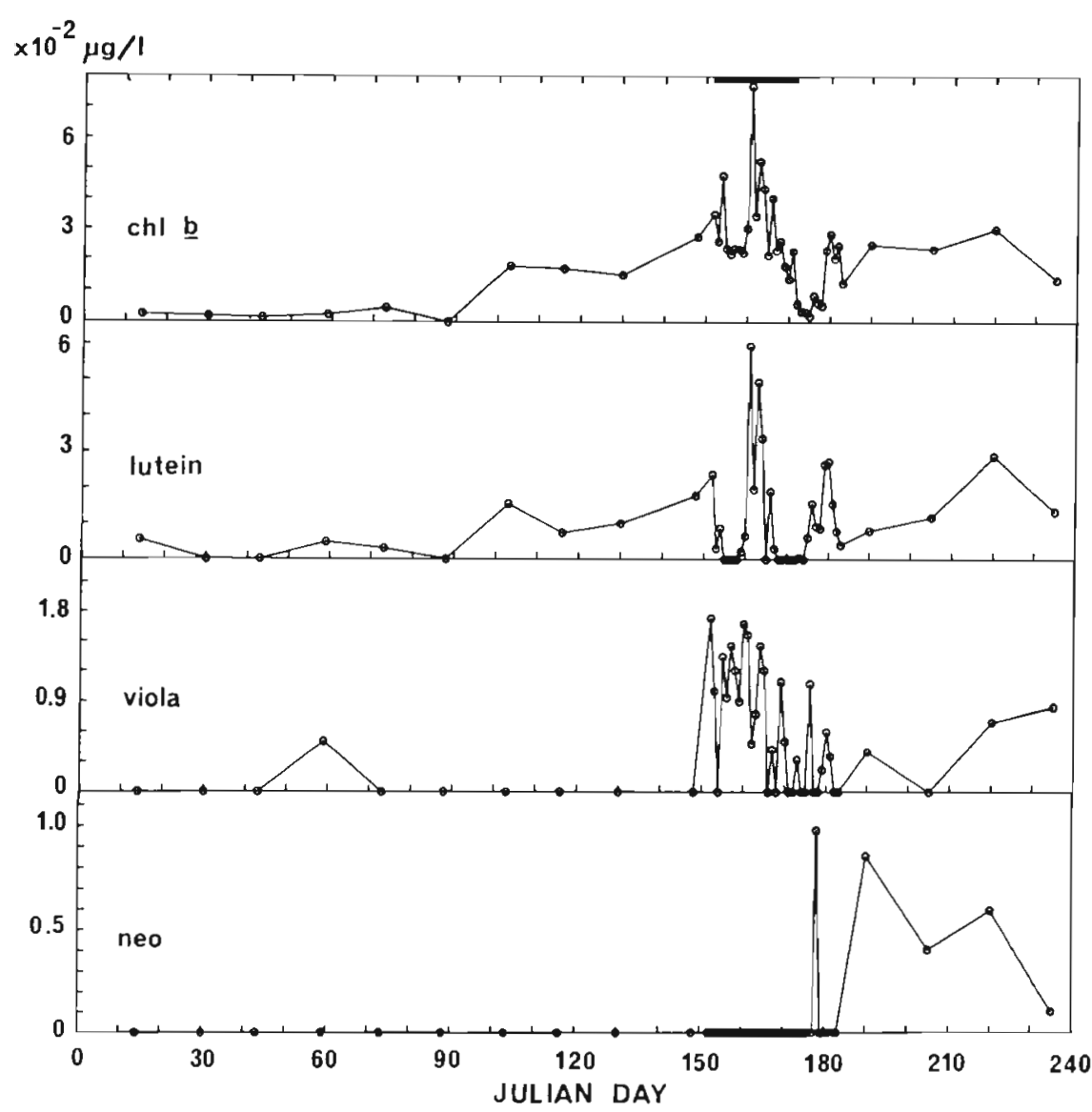

Fig. 3. Concentrations of the green algal pigments chlorophyll $b$, lutein, violaxanthin and neoxanthin $\left(\mu \mathrm{g} \mathrm{l}^{-i}\right)$ during the period Jan to Aug 1985 
Fig. 4. Concentrations of the cryptomonad pigments alloxanthin and $\alpha$ carotene $\left(\mu \mathrm{g} \mathrm{l}^{-1}\right)$ during the period Jan to Aug 1985

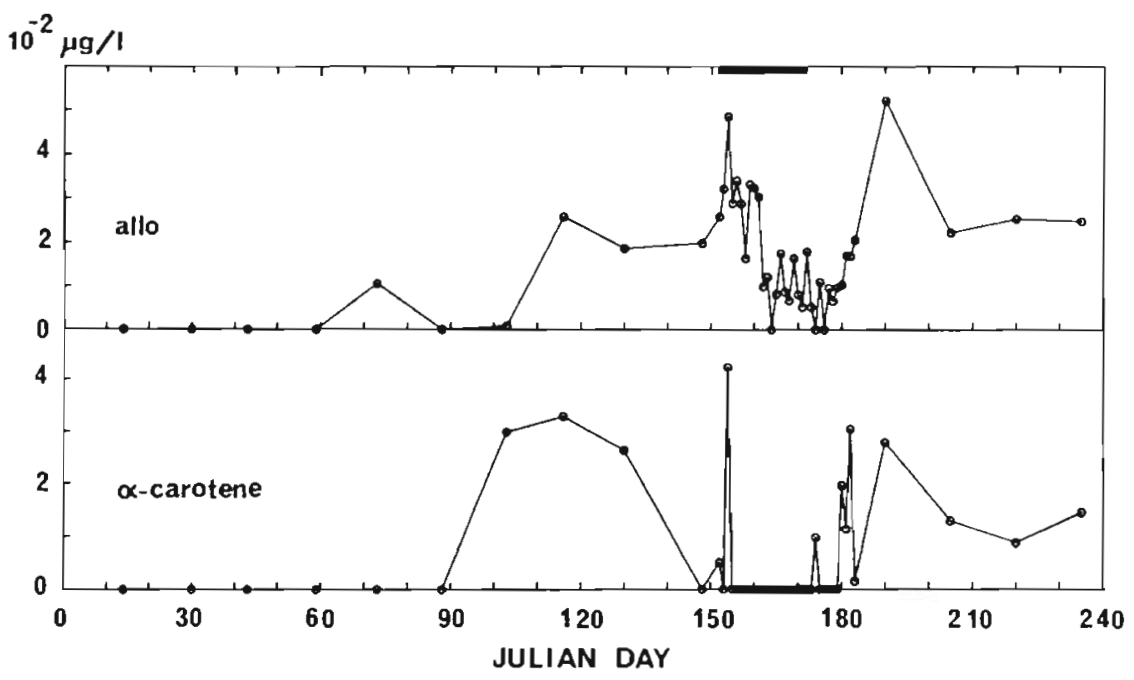

to pigments which are also found in diatoms. The alloxanthin concentration was rather stable from Day 116 till Day 161. The concentration was about $3 \times$ lower during the culmination and the decline of the diatom bloom. Since nannoplankton cell counts are not available, it is not possible to say whether the cryptomonad density, or the pigment content per cell, decreased. It should be noted that the alloxanthin concentration does not show the obvious decrease observed in diatom and green algal pigments (Days 171 to 174). This indicates that cryptomonad pigment concentrations and probably cell densities were not affected by the same phenomenon as the green algae and the diatoms.

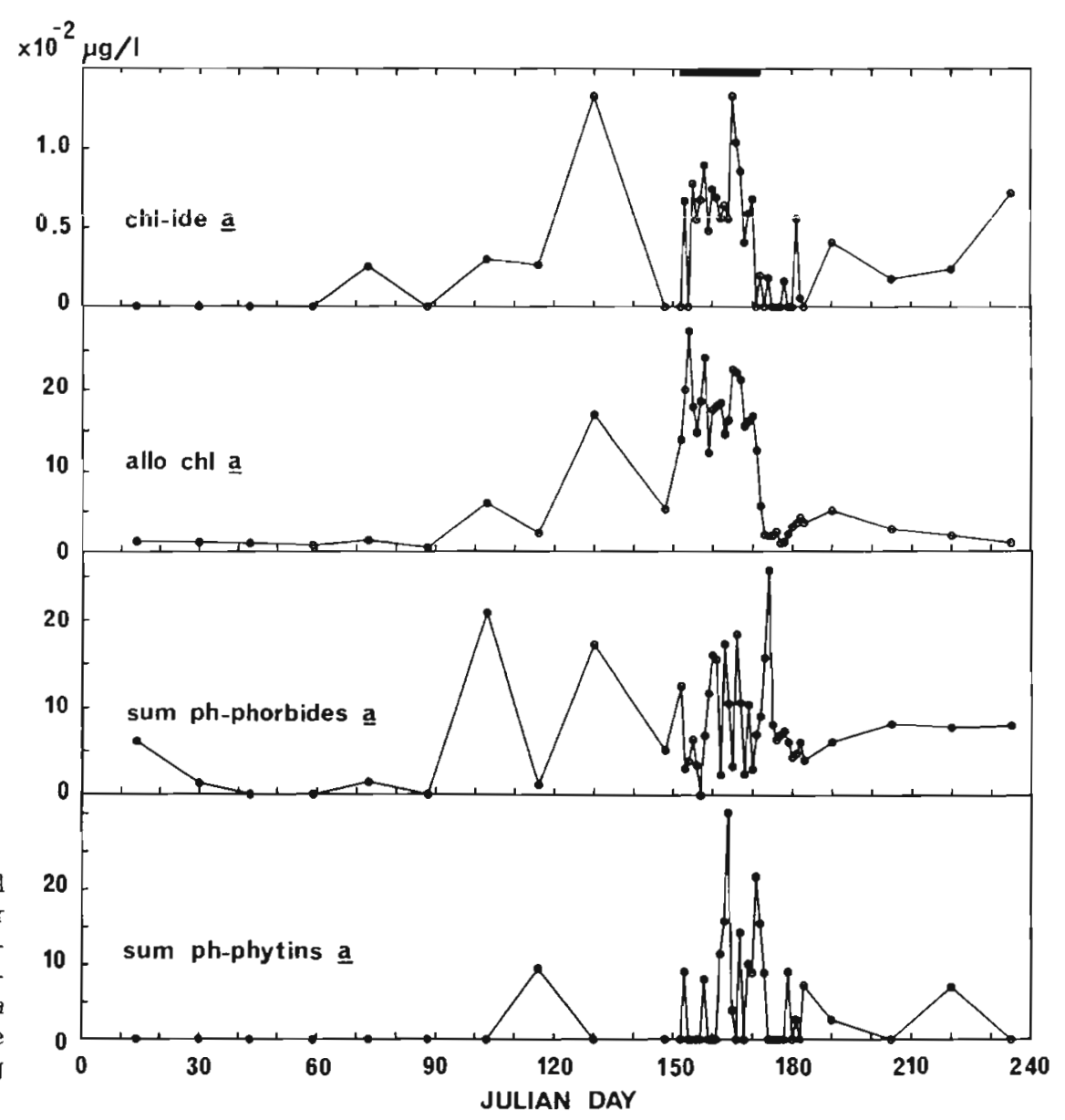

Fig. 5. Concentrations of the chlorophyll $a$ derivatives chlorophyllide $a$, allomer chlorophyll $a$, the sum of phaeophorbide $a$ and the phaeophorbide a-like derivatives, and the sum of phaeophytin a and the phaeophytin a-like derivative ( $\mu \mathrm{g} \mathrm{l}^{-1}$ ) during the period Jan to Aug 1985 


\section{Chlorophyll a derivatives}

The various chlorophyll a degradation products are summarized in Fig. 5 because of their importance as an indicator of physiological state and relationships in plankton ecosystems (see 'Introduction').

Phaeophorbide a-like derivatives

Several small peaks, with retention times between 7.8 and $11.4 \mathrm{~min}$, were observed on the fluorescence chromatograms in the region of the phaeophorbide $a$ peak (Fig. 1). Comparison of the retention times showed that there were 7 different components; 2 of them were somewhat more polar and 4 were less polar than phaeophorbide a. These 6 unknown components are probably phaeophorbide a-like chlorophyll derivatives. The concentrations were too low to verify this. The concentrations of phaeophorbide $a$ and the phaeophorbide a-like derivatives are shown in Fig. 6. Phaeophorbide $a$ and phaeophorbide a-like 2 and 6 were observed during the whole investigation period, whilst the other phaeophorbide a-like derivatives were

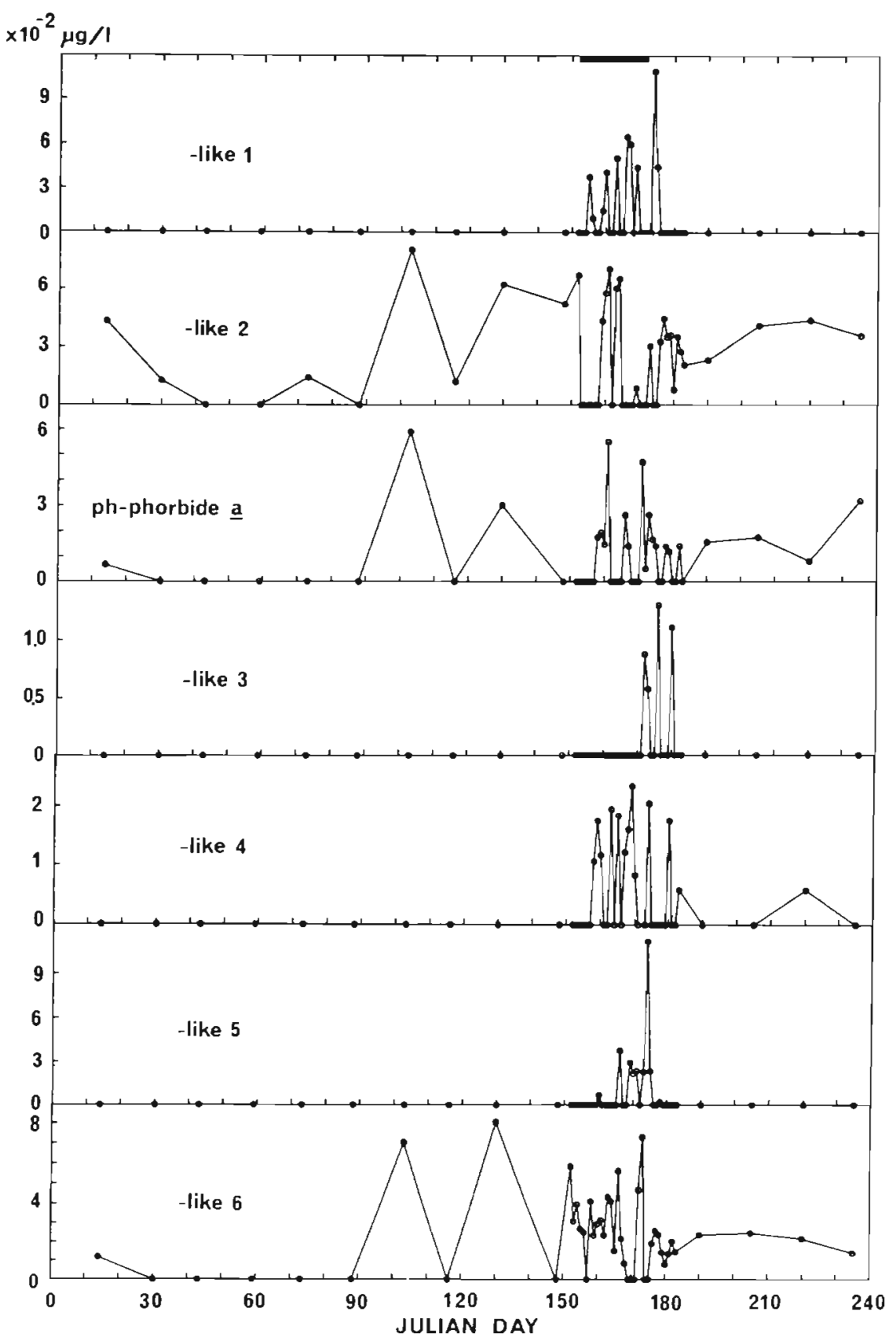

Fig. 6. Concentrations of phaeophorbide $a$ and the 6 phaeophorbide a-like chlorophyll derivatives $\left(\mu \mathrm{gl}^{-1}\right)$ during the period Jan to Aug 1985 
only detected during the bloom period. Phaeophorbide a-like 3 and 4 appeared in much lower concentrations than the other compounds. Most of the compounds were detected at the end of the period in association with rather stable diatom densities (Days 158 to 161). At the culmination of the bloom, phaeophorbide a and phaeophorbide a-like 1, 4, 5 and 6 were present in moderate concentrations. All compounds were observed during the decline of the bloom, often attaining high concentrations. It seems likely that the 7 derivatives do not have the same origin (e.g. different zooplankters, different feeding rates etc.), as their concentration patterns are quite different. The sum of the concentrations of these 7 phaeophorbide a-like derivatives was highest at the end of the decline of the bloom (Fig. 5).

\section{Phaeophytin a-like derivatives}

Two different phaeophytin a-like peaks were observed (Fig. 1). The peak with the shorter retention time corresponds to that of the phaeophytin a standard. Both derivatives were observed in high concentrations just before the culmination of the bloom (Days 164 and 165; Fig. 7). Phaeophytin a obtained its highest concentrations during the decline of the bloom, when the phaeophytin a-like derivative was absent. During the period of new chlorophyll a increase (Days 178 to 183), the phaeophytin a-like derivative was present and phaeophytin a was not detected. This indicates that the 2 derivatives probably have a different origin. The total phaeophytin a concentration (sum of phaeophytin $a$ and phaeophytin a-like) showed its maximum concentrations before the culmination and during the decline of the bloom (Fig. 5).

\section{Chlorophyllide a}

Chlorophyllide a was only found in very low concentrations, which showed a somewhat particulate pattern (Fig. 7). During the bloom period the concentration was relatively high. The chlorophyllide a concentration also showed the fluctuations observed in the diatom pigments on Days 158 and 159. The highest concentrations were observed on Day 130 and just before the culmination of the bloom (Day 165).

\section{Allomere and isomere chlorophyll a}

On all chromatograms there was a small peak just in front of the chlorophyll a peak (Fig. 1). This peak is probably due to allomere chlorophyll $a$, although an identification was not carried out. The concentrations of this pigment (Fig. 5) followed closely that of
Fig. 7 Concentrations of phaeophytin a and the phaeophytin a-like chlorophyll derivative ( $\mathrm{g} \mathrm{l}^{-1}$ ) during the period Jan to Aug 1985

Fig. 8. The sum of all chlorophyll a derivatives:chlorophyll a ratio during the period Jan to Aug 1985
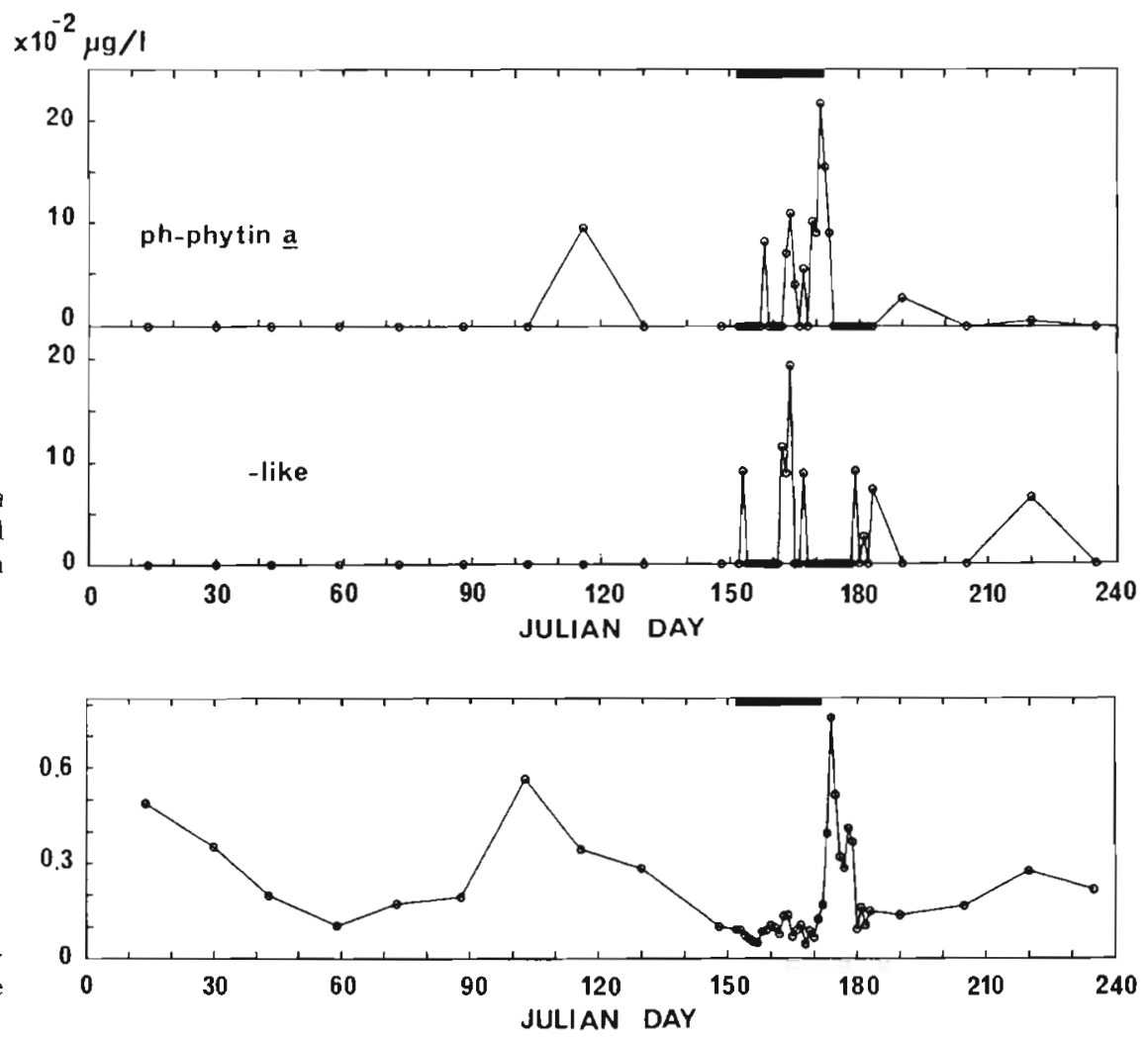


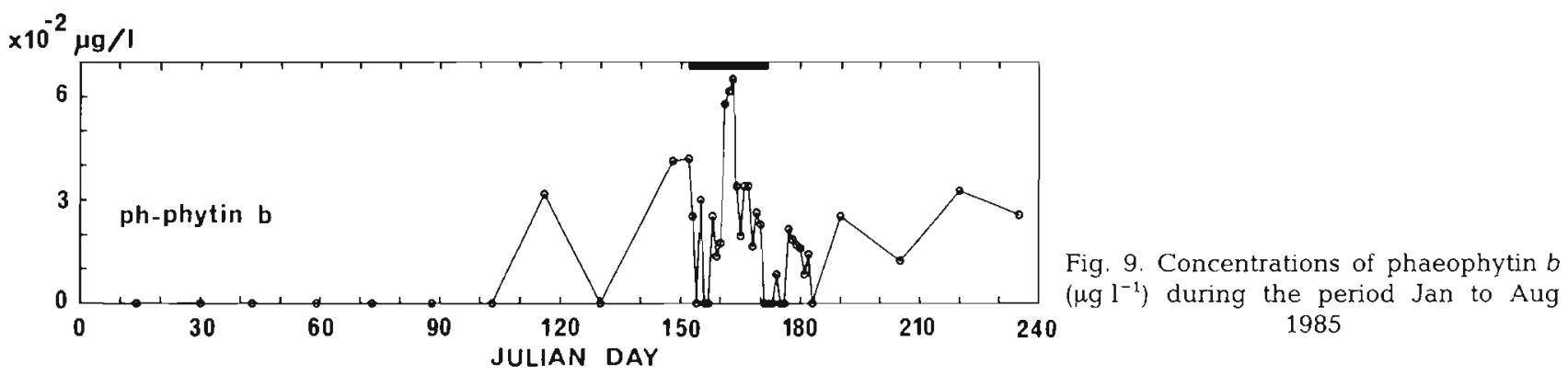

chlorophyll a. Isomere chlorophyll a was never detected during this series of analyses.

$\Sigma$ chlorophyll a derivatives : chlorophyll a ratio

The sum of all chlorophyll a derivatives: chlorophyll a ratio shows that the degradation products can attain up to $75 \%$ of the actual chlorophyll a concentration (Fig. 8).

\section{Chlorophyll $b$ derivatives}

The concentration of phaeophytin $b$, degradation product of chlorophyll $b$, is shown in Fig. 9. The concentration fluctuated similarly to that of chlorophyll $b$. Other chlorophyll $b$ degradation products were not observed during this series of analyses.

\section{Correspondence analysis}

In order to summarize in a concise way this relatively large amount of information, correspondence analysis (cf. Benzecri 1970, Teil 1975) has been chosen. For this analysis only the concentrations of the most abundant pigments were used together with the sums of the phaeophorbide a-like and of the phaeophytin a-like derivatives. Pigment concentrations were rescaled so that all ranges were similar.

Projections of the 46 samples and 12 pigments on the plane of the first 2 axes of the resulting diagram (Fig. 10) account for $60 \%$ of the variability. Inclusion of the third axis (not shown) brings the total up to $78 \%$. Samples from the bloom period are found to the right of Axis 1 because of high concentrations of the diatom pigments chlorophyll $a$, chlorophyll $c$ and fucoxanthin. On Axis 2, the bloom samples are found together, except the samples of Days 163 and 164 which show high $\Sigma$ phaeophytin a-like concentrations. The decline of the bloom (Days 171 to 176) can be followed clearly because of the decrease in diatom pigment concentrations and the increase of $\Sigma$ phaeophytin a-like and $\Sigma$

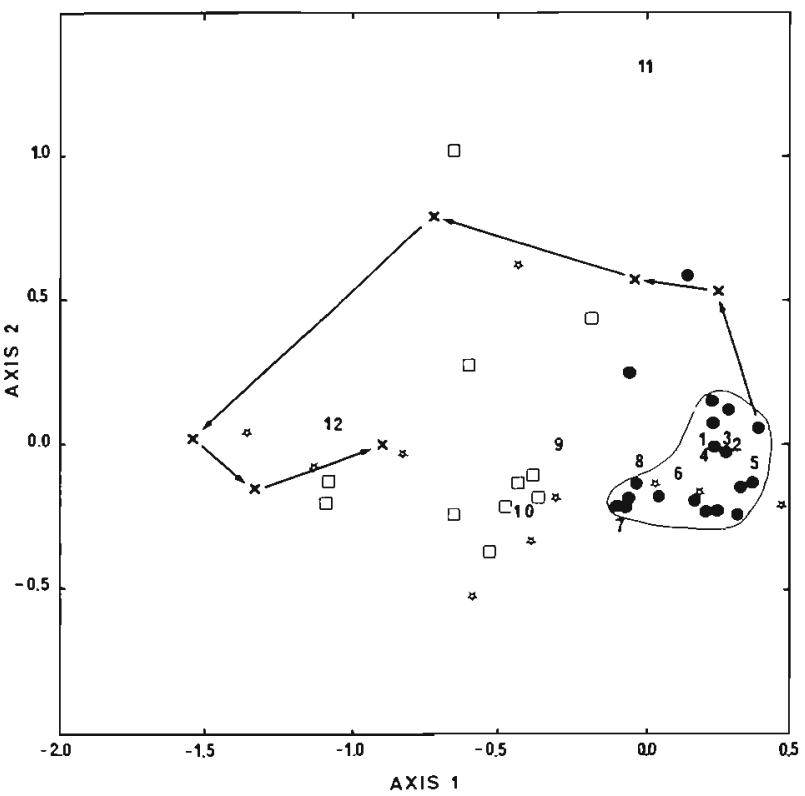

Fig. 10. Plane of the first and the second axes determined by correspondence analysis of phytoplankton pigment data (46 samples, 12 pigments) from the coastal waters of Roscoff sampled during the period Jan to Aug 1985. Sample points: $(*)$ pre-bloom period (Days 14 to 148$) ;(\bullet)$ bloom period (Days 152 to 170 ); (X) decline (Days 171 to 176); ( $\square$ ) post-bloom period. Pigment points: 1 , chlorophyll $a_{i} 2$, chlorophyll $c_{i} 3$, fucoxanthin; 4, diadinoxanthin; 5, neofucoxanthin; 6, allomere chlorophyll $a ; 7$, chlorophyllide $a ; 8, \beta$-carotene; 9 chlorophyll $b ; 10$, alloxanthin; $11, \Sigma$ phaeophytin $a$ and phaeophytin a-like derivative; $12, \Sigma$ phaeophorbide a and phaeophorbide a-like derivatives

phaeophorbide a-like concentrations. Samples from the pre-bloom period (Days 14 to 148 ) and the postbloom period (Days 177 to 235) are dispersed, which indicates a great variability in pigment composition and shifts in pigment abundances, thus reflecting changes in the phytoplankton community.

\section{DISCUSSION}

The pigment composition of the phytoplankton in the coastal waters of Roscoff reflected clearly the bloom of the diatom Rhizosolenia delicatula from 1 to 
20 June (Days 152 to 172). The chlorophyll a concentration pattern was similar to that of the major diatom pigments chlorophyll $c$ and fucoxanthin (cf. van den Hoek 1978, Parsons et al. 1984) indicating that the other algal classes did not contribute much to the concentration of this common pigment. Pigment concentrations were rather low before and after the diatom bloom (e.g. chlorophyll a less than $1 \mu \mathrm{g} \mathrm{l}^{-1}$ ). During the bloom the concentrations were much higher (chlorophyll a between 2.8 and $4.8 \mu \mathrm{g} \mathrm{l}^{-1}$ ). The maximum observed chlorophyll a concentration was within the range of previous observed annual maxima (between 0.92 and $6.2 \mu \mathrm{g} \mathrm{l}^{-1}$ with one exceptional value of $12 \mu \mathrm{g} 1^{-1}$; Grall \& Jacques 1964, Grall 1972a, b, Riaux \& Grall 1982, Martin-Jézéquel 1983, Wafar et al. 1983).

The phytoplankton community at Roscoff consists besides diatoms mainly of cryptomonads (Grall 1972a, Riaux 1983). This is confirmed by the detection of alloxanthin and $\alpha$-carotene. Peridinin, the characteristic dinoflagellate pigment (cf. van den Hoek 1978, Parsons et al. 1984), was never detected throughout the study period. This indicates that photosynthetic dinoflagellates are not important in the coastal waters of Roscoff, as was observed by Grall (1972a) and in the present study. The continuous presence of green algae, as revealed by the pigments chlorophyll $b$ and lutein, was unknown until now. Grall \& Jacques (1964) noticed the presence of chlorophyll $b$, but the spectrophotometric technique used is not reliable (Lorenzen \& Jeffrey 1980). In the nearby Bay of Brest, cryptomonads were also observed in the nannoplankton (Quéguiner \& Tréguer 1984); however, here too, green algae were not mentioned. This probably because fixation with Lugol's solution is not appropriate for fragile nannoplankton (Lorenzen 1981, Gieskes \& Kraay 1986). Unexpected high concentrations of chlorophyll $b$ were found by Jeffrey $(1974,1976)$ and recently in many samples all over the world (Lorenzen 1981, Gieskes \& Kraay 1983b, 1984, 1986, Hallegraeff \& Jeffrey 1984, Bidigare et al. 1986, Burkill et al. 1986, Trees et al. 1986).

The pigments alloxanthin, chlorophyll $b$ and lutein show a less pronounced variation throughout the sampling period than the diatom pigments. This agrees with previous observations in various parts of the world (Sournia 1968, Grall 1972a, Hallegraeff 1981, Quéguiner \& Tréguer 1984, Hallegraeff \& Reid 1986) that the nannoplankton does not show the important seasonal variation observed in the microplankton. Epifluorescence counts made at approximately fortnightly intervals show a fairly constant abundance of picoplankton in Roscoff waters (ca $10^{6}$ cells $1^{-1}$, of which about $50 \%$ consists of cyanobacteria; D. Vaulot pers. comm.).
Alloxanthin (cryptomonads), chlorophyll $b$ and lutein (green algae) and chlorophyll $c$ and fucoxanthin (diatoms) exhibit different concentration patterns, indicating that the presence of one of the algal classes had no important influences on the other classes. Nevertheless, it is surprising that the chlorophyll $b$ concentrations also decreased during the decline of the diatom bloom. Explanation of this coincidence necessitates further studies on the ecological requirements of the respective groups.

None of the phaeophorbide-like chlorophyll a derivatives were detected at high concentrations. However, during the decline of the bloom (Day 174) phaeophorbide $a$-like 1 and 2 each attained about $25 \%$ of the chlorophyll a concentration. Phaeophorbide a-like derivatives were found in faecal pellets of copepods (Vernet 1983, Gieskes \& Kraay 1986) and Hawkins et al. (1986) observed that phaeophorbide a-like derivatives were the most abundant chlorophyll a degradation product in the faeces of the mussel Mytilus edulis. The observed derivatives are probably the result of zooplankton grazing. This grazing was probably very important during the bloom, since the mesozooplankton showed its annual maximum density during this period (Sournia et al. 1987). The hypothesis of Vernet (1983), that increased degradation is reflected by increased polarity of the phaeophorbide $a$ like derivatives, was confirmed by Roy (1986). The present results, however, do not support this hypothesis, as the more polar compounds do not show any increase following high concentrations of the less polar compounds. However, this difference can be caused by photo-oxidation of phaeophorbide a-like derivatives (cf. SooHoo \& Kiefer 1982a, b).

Phaeophytina and the same phaeophytin a-like derivative were also observed in phytoplankton samples and copepod faecal pellets (Vernet 1983, Gieskes \& Kraay 1986, Roy 1986). Engelkes (1985), however, observed 2 phaeophytin a-like derivatives in copepod grazing experiments and concluded that only phaeophytin $a$-like derivatives and no phaeophytin $a$ are formed during copepod grazing. Our results confirm this conclusion, since the highest concentrations of the phaeophytin a-like derivative coincided with the maximum mesozooplankton density (Day 161; Sournia et al. 1987), while high phaeophytin a concentrations were observed when the mesozooplankton density was much lower. The phaeophytins seem to be a less important chlorophyll a degradation product than phaeophorbides, since they were less often detected and the amount of phaeophytins was much lower than the sum of the phaeophorbides.

Chlorophyllide a was only observed in low concentrations (less than $1 \%$ of chlorophyll a) with highest concentrations just before the culmination of the 
bloom. These high concentrations coincide with high concentrations of the phaeophytin a-like derivative, which indicates copepod grazing. The chlorophyllide $a$ is probably the result of superfluous feeding by copepods (i.e. producing disrupted but not ingested cells; cf. Gieskes \& Kraay 1980). Much higher chlorophyllide a concentrations in respect to chlorophyll a were observed by Gieskes \& Kraay (1980). Hallegraeff (1981), Gowen et al. (1983) and Ridout \& Morris (1985). High chlorophyllide a concentrations were in these 4 cases associated with a bloom of the diatoms Skeletonema costatum and/or Chaetoceros sp. Degradation of chlorophyll $a$ to chlorophyllide $a$ is known to occur readily during the filtration of fragile chlorophyllase-containing diatoms (Jeffrey \& Hallegraeff unpubl. in Hallegraeff 1981) and especially with S. costatum (Suzuki \& Fujita 1986). We did not observe high chlorophyllide a concentrations and $S$. costatum and Chaetoceros spp. were only minor components of the diatom populations on the days when pigments were analysed.

Phaeophytin $b$ was detected in most of the samples, whereas it was never or hardly ever detected in other studies (Sartory 1985, Bidigare et al. 1986, Trees et al. 1986). Phaeophytin $b$ is probably, like the phaeophytin a-like derivative, the result of copepod grazing. Thus, the presence of phaeophytin $b$ indicates that copepods were grazing directly on the small nannoplanktonic green algae. Protozoa were not rare, but since they are able to digest pigments and degradation products of pigments (Burkill et al. 1986, Klein et al. 1986), it is not likely that the observed phaeophytin $b$ resulted from protozoan grazing.

The usefulness of correspondence analysis in biological oceanography has been shown (e.g. Malmgren et al. 1978). In the present study the phytoplankton pigment composition as determined by HPLC is used for the first time in a correspondence analysis. The samples taken during the bloom period are all grouped together and the decline of the bloom is clearly shown, whereas the pre- and post-bloom samples are not grouped because of their great variability. The inclusion of the pigment points among the sample points proved to be particularly demonstrative in the diagram.

Acknowledgements. We thank Claude Le Roux and Jean-Luc Douville for adapting the computer programs and their help with running them, Catherine Riaux-Gobin for helpful remarks on the work and 2 anonymous referees, whose comments were used to improve the manuscript. This study was partly supported by contract IFREMER 85-1430507. B.K. would like to acknowledge the financial support given by the Minna-James-Heineman-Stiftung.

\section{LITERATURE CITED}

Abaychi, J. K., Riley, J. P. (1979). The determination of phytoplankton pigments by High-Performance Liquid Chromatography. Analytica chim. Acta 107: 1-11

Benzecri, J. P. (1970). La pratique de l'analyse des correspondances. Cahier no. 2 du Laboratoire des Statistiques Mathématiques, Faculté des Sciences, Paris

Bidigare, R. R., Frank, T. J., Zastrow, C., Brooks, J. M. (1986). The distribution of algal chlorophyls and their degradation products in the Southern Ocean. Deep Sea Res. 33: 923-937

Burkill, P. H., Mantoura, R. F. C., Llewellyn, C. A., Owens, N. P. J. (1986). Microzooplankton grazing and selectivity of phytoplankton in coastal waters. Mar. Biol. 93: 581-590

Conover, R. J., Durvasula, R., Roy, S., Wang, R. (1986). Probable loss of chlorophyll-derived pigments during passage through the gut of zooplankton, and some of the consequences. Limnol, Oceanogr. 31: 878-887

Daley, R. J. (1973). Experimental characterisation of lacustrine chlorophyll diagenesis. II. Bacterial, viral and herbivore grazing effects. Arch. Hydrobiol. 72: 409-439

Engelkes, M. M. (1985). Derivaatvorming en afbraak van algenpigmenten door copepodenbegrazing gemeten na scheiding met HPLC. Studentenverslag, N.I.O.Z, Texel, The Netherlands

Gieskes, W. W. C., Kraay, G. W. (1980). Primary productivity and phytoplankton pigment measurements in the northern North Sea during FLEX '76. 'Meteor' Forsch.-Ergebn. A. 22: $105-112$

Gieskes, W. W. C., Kraay, G. W. (1983a). Dominance of Cryptophyceae during the phytoplankton spring bloom in the central North Sea detected by HPLC analysis of pigments. Mar. Biol. 75: 179-185

Gieskes, W. W. C., Kraay, G. W. (1983b). Unknown chlorophyll $a$ in the North Sea and the tropical Atlantic Ocean revealed by HPLC analysis. Limnol. Oceanogr. 28: $757-766$

Gieskes, W. W. C., Kraay, G. W. (1984). Phytoplankton, its pigments, and primary production at a central North Sea station in May, July and September 1981. Neth. J. Sea Res. 18: $51-70$

Gieskes, W. W. C., Kraay, G. W. (1986). Analysis of phytoplankton pigments by HPLC before, during and after mass occurrence of the microflagellate Corymbellus aureus during the springbloom in the open northern North Sea in 1983. Mar. Biol. 92: 45-52

Gowen, R. J., Tett, P., Wood, B. J. B. (1983). Changes in the major dihydroporphyrin plankton pigments in two Scottish sea-lochs. J. mar. biol. Ass. U.K. 63: 27-36

Grall, J.-R. (1972a). Recherches quantitatives sur la production primaire du phytoplancton dans les parages de Roscoff. Thése Université Paris-VI

Grall, J.-R. (1972b). Développement 'printanier' de la diatomée Rhizosolenia delicatula près de Roscoff. Mar. Biol. 16: $41-48$

Grall, J.-R., Jacques, G. (1964). Etude dynamique et variations saisonnières du plancton de la région de Roscoff. Cah. Biol. mar. 5: 423-455

Hallegraeff, G. M. (1981). Seasonal study of phytoplankton pigments and species at a coastal station off Sydney importance of diatoms and the nanoplankton. Mar Biol. 61: 107-118

Hallegraeff, G. M., Jeffrey, S. W. (1984). Tropical phytoplankton species and pigments of continental shelf waters of North and North-West Australia. Mar. Ecol. Prog. Ser. 20: 59-74 
Hallegraeff, G. M., Reid, D. D. (1986). Phytoplankton species successions and their hydrological environment at a coastal station off Sidney. Aust. J. mar. Freshwat. Res. 37: $361-371$

Hawkins, A. J. S., Bayne, B. L., Mantoura, R. F. C., Llewellyn, C. (1986). Chlorophyll degradation and absorption throughout the digestive system of the blue mussel Mytilus edulis L. J. exp. mar. Biol. Ecol. 96: 213-223

Hoek, C., van den (1978). Algen. Einführung in die Phycologie. Thieme Verlag, Stuttgart

Jeffrey, S. W. (1974). Profiles of photosynthetic pigments in the ocean using thin-layer chromatography. Mar. Biol. 26: $101-110$

Jeffrey, S. W. (1976). A report of green algal pigments in the central North Pacific Ocean. Mar. Biol. 37: 33-37

Jeffrey, S. W. (1980). Algal pigment systems. In: Falkowski, P. G. (ed.) Primary productivity in the sea. Plenum Press. New York, p. 33-58

Jeffrey, S. W. (1981). An improved thin-layer chromatographic technique for marine phytoplankton pigments. Limnol. Oceanogr. 26: 191-197

Klein, B., Gieskes, W. W. C., Kraay, G. W. (1986). Digestion of chlorophylls and carotenoids by the marine protozoan Oxymhis marina studied by HPLC analysis of algal pigments. J. Plankton Res. 8: 827-836

Lorenzen, C. J. (1967). Vertical distribution of chlorophyll and phaeopigments: Baja Californica. Deep Sea Res. 14: $735-745$

Lorenzen, C. J. (1981). Chlorophyll $b$ in the eastern North Pacific Ocean. Deep Sea Res. 28A: 1049-1056

Lorenzen, C. J., Jeffrey, S. W. (1980). Determination of chlorophyll in seawater. UNESCO technical papers in marine science No. 35

Malmgren, B., Oviatt, C., Gerber, R., Jeffries, H. P. (1978). Correspondence analysis: applications to biological oceanographic data. Estuar. coast. mar. Sci. 6: 429-437

Mantoura, R. F. C., Llewellyn, A. C. (1983). The rapid determination of algal chlorophyll and carotenoid pigments and their breakdown products in natural waters by reverse-phase High-Performance Liquid Chromatography. Analytica chim. Acta 151: 297-314

Marker, A. F. H. Hopgood, H. A., Randall, C. F. (1986). Studies on epilithic and epiphytic diatoms in a chalkstream: comparative estimates of chlorophyll a and its derivatives. Br. phycol. J. 21: 171-182

Martin-Jézéquel, V. (1983). Facteurs hydrologiques et phytoplancton en Baie de Morlaix (Manche Occidentale). Hydrobiologia 102: 131-143

Meeks, J. C. (1974). Chlorophylls. In: Stewart, W. D. P. (ed.) Algal physiology and biochemistry. Botanical monographs, Vol. 10. Blackwell Scientific Publications, Oxford, p. $161-175$

Parsons, T. R., Takahashi, M., Hargrave, B. (1984). Biological oceanographic processes, 3rd edn. Pergamon Press, Oxford

Quéguiner, B., Tréguer, P. (1984). Studies on the phytoplankton in the Bay of Brest (Western Europe). Seasonal variations in composition, biomass, and production in relation to hydrological and chemical features (1981-1982). Botanica mar. 27: 449-459

Riaux, C. (1983). Microphytes de l'interface 'eau-sediment' dans une ria de Bretagne Nord: peuplements, biomasse, production, cycle annuel, variabilité à court terme. Thése Université Paris-VI

Riaux, C., Grall, J.-R. (1982). Hydrologie et biomasse phytoplanctonique dans une estuaire de Bretagne Nord, La Penzé. Int. Revue ges. Hydrobiol. 67: 387-404

Ridout, P. S., Morris, R. J. (1985). Short-term variations in the pigment composition of a spring phytoplankton bloom from an enclosed experimental ecosystem. Mar. Biol. 87: 7-11

Roy, S. (1986). Marine chloropigments: chromatographic measurement in phytoplankton and transformations in algal cultures and a spring bloom event in a marine bay. Ph.D. thesis, Dalhousie University, Halifax

Sartory, D. P. (1985). The determination of algal chlorophyllous pigments by High Performance Liquid Chromatography and spectrophotometry. Wat. Res. 19: 605-610

SooHoo, J. B., Kiefer, D. A. (1982a). Vertical distribution of phaeopigments. I. A simple grazing and photooxidative scheme for small particles. Deep Sea Res. 12A: 1539-1551

SooHoo, J. B., Kiefer, D. A. (1982b). Vertical distribution of phaeopigments. II. Rates of production and kinetics of photooxidation. Deep Sea Res. 12A: 1553-1563

Sournia, A. (1968). Variations saisonnières et nycthémérales du phytoplancton marin et de la production primaire dans une baie tropicale, à Nosy-Bé (Madagascar). Int. Revue ges. Hydrobiol. 53: 1-76

Sournia, A., Birrien, J.-L., Douvillé, J.-L., Viollier, M. (1987). A daily study of the diatom spring bloom at Roscoff (France) in 1985. I. The spring bloom within the annual cycle. Estuar. coast. Shelf Sci. (in press)

Strickland, J. D. H., Parsons, T. R. (1968). A handbook of seawater analysis. Bull. Fish. Res. Bd Can. 167: 1-310

Suzuki, R., Fujita, Y. (1986). Chlorophyll decomposition in Skeletonema costatum: a problem in chlorophyll determination of water samples. Mar. Ecol. Prog. Ser. 28: 81-85

Teil, M. (1975). Correspondence factor analysis: an outline of its method. Math. Geol. 7: 3-12

Trees, C. C., Bidigare, R. R., Brooks, J. M. (1986). Distribution of chlorophylls and phaeopigments in the Northwestern Atlantic Ocean. J. Plankton Res. 8: 447-458

Vernet, M. (1983). Marine phytoplankton pigments: methods and ecology. Ph.D. thesis, University of Washington

Wafar, M. V. M., Le Corre, P., Birrien, J. L. (1983). Nutrients and primary production in permanently well-mixed temperate coastal waters. Estuar. coast. Shelf Sci. 17: 431-446

This article was submitted to the editor; it was accepted for printing on February 6,1987 